\section{Concurrent increases in brain electrical activity and intracranial blood flow velocity during low-dose ketamine anaesthesia}

Eberhard Kochs MD, Christian Werner MD, William E. Hoffman* PhD, Oliver Möllenberg MD, Jochen Schulte am Esch MD
The purpose of the present study was to assess the effects of low-dose ketamine on spontaneous brain electrical activity (EEG) and intracranial blood flow velocity. Twenty healthy volunteers were divided into two groups: Group $I(n=10)$ received $0.25 \mathrm{mg} \cdot \mathrm{kg}^{-1}$ ketamine iv; Group $I I(n=10)$ received $0.5 \mathrm{mg} \cdot \mathrm{kg}^{-1}$ ketamine iv. Mean arterial blood pressure (MAP), heart rate (HR), end-tidal $\mathrm{PCO}_{2}\left(\mathrm{PETCO}_{2}\right)$, and arterial oxygen saturation $\left(\mathrm{SaO}_{2}\right)$ were measured. The EEG was recorded from temporo-occipital recording sites over both hemispheres. Blood flow velocity in the middle cerebral artery was measured using a transcranial Doppler ultrasound system. All variables were evaluated at baseline and for $60 \mathrm{~min}$ following ketamine. Administration of ketamine resulted in increases of MAP and HR in both groups to a similar degree. The PETCO $\mathrm{O}_{2}$ and $\mathrm{SaO}_{2}$ did not change in either group over time. Ketamine caused a dose-dependent, transient shift in the EEG to synchronous high-voltage slow waves with an increase in total power (Group I: $301 \pm 38 \%$; Group II: $104 \pm 28 \%$ ). These changes were associated with dose-dependent increases in mean blood flow velocity (Group I: $35 \pm 7 \%$; Group II: $68 \pm$ $10 \%)$. Our data suggest that increases in intracranial blood flow velocity are closely correlated to increases in neuronal activity and are not secondary to changes in systemic haemodynamic variables.

\section{Key words}

ANAESTHETICS, INTRA VENOUS: ketamine; BRAIN: blood flow velocity, elctroencephalography; MEASUREMENT TECHNIQUES: Doppler ultrasound, transcranial.

From the Departments of Anaesthesiology, University Hospital Eppendorf, Hamburg, Germany and *University of IllinoisChicago/Michael Reese Hospital, Chicago, IL.

Address correspondence to: Dr. Eberhard Kochs, Department of Anaesthesiology, University Hospital Eppendorf, Martinistrasse 52, 2000 Hamburg 20, Germany.

Accepted for publication 17th May, 1991.
Le but de cette étude était d'évaluer les effets de petites doses de kétamine sur l'activité electrique spontanée du cerveau (EEG) en corrélation avec le changement de la vélocité du débit sanguin cérébral. Vingt volontaires sains étaient divisés en deux groupes d' une façon randomisée. Le groupe I $(n=10)$ a recu une dose de 0,25 $\mathrm{mg} \cdot \mathrm{kg}^{-1}$ de ketamine; le groupe II $(\mathrm{n}=10)$ a reçu $0,5 \mathrm{mg} \cdot \mathrm{kg}^{-1}$ de ketamine par voie intraveineuse. Les paramètres suivants étaient mésurés : la pression arterielle moyenne (MAP), la fréquence cardiaque ( $\mathrm{HR})$, la $\mathrm{PCO}_{2}$ en fin d'expiration $\left(\mathrm{PETCO}_{2}\right)$ et la saturation artérielle en oxygène $\left(\mathrm{SaO}_{2}\right)$. L'EEG était enregistré à l'aide d'électrodes adhésives placées sur la région temporo-occipitale des deux hémisphères. La vélocité du débit sanguin dans l'artère cérébrale moyenne (MCA) était mesurée par un doppler trans-crânien (TCD). Tous les paramètres étaient évalués au début et jusqu' aux 60 minutes après l'application de kétamine. Dans les deux groupes, l'administration de kétamine évoquait une augmentation de la pression artérielle moyenne et de la fréquence cardiaque au même niveau ; la $\mathrm{PETCO}_{2}$ et la $\mathrm{SaO}_{2}$ n'ont subi aucune modification pendant toute la durée du protocole. Dépendant de la dose appliquée la kétamine a évoqué une modification passagère du tracé EEG vers des ondes synchrones de basse fréquence et un voltage de grande amplitude ainsi qu'une augmentation du spectre de puissance (groupe I : $301 \pm 38 \%$; group II : $104 \pm 28 \%)$. Ces changements étaient associés à l'augmentation de la vélocité du flot sanguin cérébral. Nous concluons que les altérations des paramètres hémodynamiques cérébrales ont une meilleure corrélation avec l'activité neuronale du cerveau et ne sont pas secondaire au changement des paramètres cardiovasculaires.

There is some controversy about the effects of ketamine on brain electrical activity (EEG) and intracranial haemodynamic variables. Ketamine has been reported to depress the thalamic-median nucleus selectively. ${ }^{1,2}$ In contrast, Kayama and Iwama $^{3}$ found that the administration of ketamine resulted in functional stimulation of both neo- 
cortical and hippocampal areas. The effects of ketamine on cerebral blood flow (CBF) and cerebral oxygen consumption $\left(\mathrm{CMRO}_{2}\right)$ are also controversial. ${ }^{4-8}$ Noninvasive transcranial Doppler sonography (TCD) measures blood flow velocity in human basal cerebral arteries continuously. ${ }^{9,10}$ Since TCD does not interfere with neurophysiological recardings it may be used to correlate changes in cerebral blood flow velocity with changes in brain electrical activity. The purpose of this study was to evaluate simultaneously the effects of ketamine on EEG and intracranial blood flow velocity.

\section{Methods}

Twenty healthy volunteers (ASA physical status I; age: 27 $\pm 5 \mathrm{yr}$; female: 12 ; male: 8 ) were included in the study. This study was approved by the Institutional Ethics Committee and written informed consent was obtained. The unpremedicated subjects were randomly assigned to one of two groups. Subjects of Group I $(n=10)$ received $0.25 \mathrm{mg} \cdot \mathrm{kg}^{-1}$ ketamine $i v$ and subjects of Group II $(n=$ 10) $0.5 \mathrm{mg} \cdot \mathrm{kg}^{-1} \mathrm{ketamine} i v$. The following variables were recorded at baseline and for $60 \mathrm{~min}$ following ketamine administration: EEG, TCD, heart rate (HR, beats/min, RM300 Honeywell), mean arterial blood, pressure (MAP, mmHg; Dinamap ${ }^{(\mathbb{M}}$, Critikon), end-tidal $\mathrm{PCO}_{2}\left(\mathrm{PETCO}_{2}, \mathrm{mmHg}\right.$; Datex ${ }^{(\mathrm{TM})}$ Hoyer $)$ and arterial oxygen saturation $\left(\mathrm{SaO}_{2}, \%\right.$; Nellcor ${ }^{\mathrm{MM}}$ Draeger $)$.

\section{$E E G$}

Platinum needle electrodes (13L70, Dantec, Denmark) for EEG recordings were placed in the scalp at $\mathrm{C} 3 \mathrm{P} 3$ and C4P4 according to the International 10-20 system. For artifact control, the electro-oculogram (EOG) was recorded from supra- vs infraorbital leads with the bandpass for all recordings set at $0.5-45 \mathrm{~Hz}$. The inter-electrode impedances were kept below $5 \mathrm{kOhm}$ (at $12 \mathrm{~Hz}$ ). After amplification (BIO-V6 6 , nbn-electronics, Germany) the EEG and EOG signals were stored on magnetic tape (Store 7-DS ${ }^{\top \times}$, Racal, Great Britain). Following A/D conversion (ced 1401 Cambridge Electronics, Great Britain) and digitization (200 $\mathrm{Hz}$ sampling rate) EEG segments of $5.2 \mathrm{sec}$ duration were processed by Fast Fourier Transformation (FFT, Kaiser window, $-40 \mathrm{~dB}$ sidelobe suppression). Spectral power densities for selected frequency bands (delta: $0.5-3.9 \mathrm{~Hz}$, theta: $4.0-7.9$ $\mathrm{Hz}$, alpha: $8.0-12.9 \mathrm{~Hz}$, beta: $13.0-45.0 \mathrm{~Hz}$ ) were calculated from the amplitude spectra.

\section{$T C D$}

Blood flow velocity in the middle cerebral artery (MCA) was measured as reported previously ${ }^{9,10}$ using a pulsed transcranial Doppler ultrasound system (TC2-64B EME, Germany). The TCD device operates at $2 \mathrm{MHz}$ emitting frequency (pulse repetition: 5-10 Hz, burst width: $13 \mu \mathrm{sec}$ ). The MCA was identified by a transtemporal approach using flow direction discrimination (flow towards the probe), depth control and audio analysis. Following FFT of the Doppler frequency shift, systolic and mean flow velocity (Vsyst, Vmean; $\mathrm{cm} \cdot \mathrm{sec}^{-1}$ ) were recorded.

\section{Statistical analysis}

All results are expressed as mean \pm SEM. Comparisons were made by analysis of variance (ANOVA) for repeated measurements, followed by $t$ tests with Bonferroni corrections. Pearsons's correlation coefficients were calculated between EEG power spectra and TCD data. Statistical significance was assumed at a $P \leq 0.05$.

\section{Results}

All subjects became unconscious within $73 \pm 15 \mathrm{sec}$ after ketamine administration. Onset of unconsciousness was not different between groups. Data for HR, MAP, $\mathrm{SaO}_{2}$ and $\mathrm{PETCO}_{2}$ are shown in the Table. In both groups $\mathrm{HR}$ and MAP increased within two minutes following ketamine without intergroup differences. Haemodynamic baseline values were regained after $7 \pm 1$ min (Group I) and $13 \pm 3 \mathrm{~min}$ (Group II), respectively. The $\mathrm{SaO}_{2}$ did not change over time and $\mathrm{PETCO}_{2}$ remained constant within each group.

\section{$E E G$}

In seven subjects of Group I and eight of Group II dominant alpha-activity was present during baseline recordings. In all other subjects dominant frequency extended from fast theta to alpha frequency $(6-12 \mathrm{~Hz})$. Following ketamine administration, alpha-activity was decreased by $79 \pm 8 \%$ in both groups. At the same time synchronous high-voltage theta-activity was recorded in both groups. Theta power increased by $89 \pm 11 \%$ in Group I and by $229 \pm 29 \%$ in Group II. This was associated with dose-dependent increases in delta- (Group I: $34 \pm 6 \%$; Group II: $154 \pm 13 \%$ ) and beta-activity (Group I: $25 \pm 4 \%$; Group II: $54 \pm 6 \%$ ). As a result, total EEG-power was increased in both groups (Figure 1). In Group I this increase in total power faded within $6 \pm 2$ $\mathrm{min}$ and in Group II within $14 \pm 4 \mathrm{~min}$.

\section{$T C D$}

Following ketamine administration Vmean increased by $35 \pm 7 \%$ in Group I and by $68 \pm 10 \%$ in Group II $(P<$ 0.05 ) (Figure 2). The Vmean was different between the groups at 2 to $12 \mathrm{~min}$ following ketamine administration $(P<0.05)$. In Group I Vsyst did not change over time. In Group II Vsyst increased by $45 \pm 9 \%$ within two to five min following ketamine $(P<0.05)$. In group I baseline 
TABLE

\begin{tabular}{|c|c|c|c|c|c|c|c|c|}
\hline \multirow[b]{2}{*}{ Group } & \multicolumn{2}{|c|}{$\begin{array}{l}H R \\
\left(b \cdot \min ^{-1}\right)\end{array}$} & \multicolumn{2}{|l|}{$\begin{array}{l}M A P \\
(m m H g)\end{array}$} & \multicolumn{2}{|l|}{$\begin{array}{l}\mathrm{SaO}_{2} \\
(\%)\end{array}$} & \multicolumn{2}{|l|}{$\begin{array}{l}\mathrm{PETCO}_{2} \\
(\mathrm{mmHg})\end{array}$} \\
\hline & I & II & $I$ & $I I$ & $I$ & II & $I$ & $I I$ \\
\hline \multicolumn{9}{|l|}{$\mathrm{t}(\min )$} \\
\hline 0 & $70 \pm 4$ & $68 \pm 5$ & $87 \pm 4$ & $88 \pm 4$ & $99 \pm 1$ & $98 \pm 1$ & $41 \pm 1$ & $44 \pm 2 \dagger$ \\
\hline 2 & $90 \pm 5^{*}$ & $95 \pm 6^{*}$ & $104 \pm 5^{*}$ & $107 \pm 5^{*}$ & $99 \pm 1$ & $98 \pm 1$ & $39 \pm 1$ & $45 \pm 2$ \\
\hline 4 & $99 \pm 8^{*}$ & $101 \pm 9^{*}$ & $106 \pm 5^{*}$ & $110 \pm 5^{*}$ & $98 \pm 1$ & $99 \pm 1$ & $38 \pm 1$ & $45 \pm 2$ \\
\hline 6 & $94 \pm 8^{*}$ & $105 \pm 9^{*}$ & $101 \pm 5^{*}$ & $107 \pm 5^{*}$ & $99 \pm 1$ & $98 \pm 1$ & $39 \pm 1$ & $46 \pm 3$ \\
\hline 8 & $89 \pm 4^{*}$ & $101 \pm 10^{*}$ & $97 \pm 4^{*}$ & $104 \pm 5^{*}$ & $98 \pm 1$ & $99 \pm 1$ & $40 \pm 2$ & $44 \pm 2$ \\
\hline 10 & $76 \pm 4$ & $94 \pm 7^{*}$ & $94 \pm 4^{*}$ & $101 \pm 5^{*}$ & $98 \pm 1$ & $98 \pm 1$ & $39 \pm 1$ & $43 \pm 2$ \\
\hline 15 & $73 \pm 4$ & $85 \pm 6^{*}$ & $90 \pm 4$ & $97 \pm 5^{*}$ & $99 \pm 1$ & $99 \pm 1$ & $39 \pm 2$ & $44 \pm 2$ \\
\hline 20 & $75 \pm 4$ & $76 \pm 5$ & $91 \pm 4$ & $96 \pm 4^{*}$ & $99 \pm 1$ & $99 \pm 1$ & $40 \pm 1$ & $44 \pm 2 \dagger$ \\
\hline 60 & $69 \pm 5$ & $74 \pm 4$ & $92 \pm 4$ & $90 \pm 3$ & $99 \pm 1$ & $98 \pm 1$ & $41 \pm 2$ & $45 \pm 2$ \\
\hline
\end{tabular}

Heart rate (HR), mean arterial blood pressure (MAP), arterial oxygen saturation $\left(\mathrm{SaO}_{2}\right)$ and end-tidal $\mathrm{PCO}_{2}\left(\mathrm{PETCO}_{2}\right)$ following low-dose ketamine (mean $\pm \mathrm{SD}$ ). Group I $(n=10)$ : ketamine $0.25 \mathrm{mg} \cdot \mathrm{kg}^{-1}$; Group II $(n=10): 0.50 \mathrm{mg} \cdot \mathrm{kg}^{-1}$ ketamine; significance: * vs baseline within group; $\dagger$ vs Group I at each respective time level; $P<0.05$ ).

data were reestablished within $9 \pm 3 \mathrm{~min}$. Vsyst and Vmean were increased over a period of $15 \pm 4 \mathrm{~min}$ following ketamine in Group II.

\section{Correlation between EEG and TCD}

The correlation of increases in theta-activity and Vmean was $\mathrm{r}=0.79(P<0.01)$ in Group $\mathrm{I}$ and $\mathrm{r}=0.86(P<$ $0.01)$ in Group II. Correlations between MAP and Vmean were $\mathrm{r}=0.41(P>0.05)$ in Group $\mathrm{I}$ and $\mathrm{r}=0.49(P>$ 0.05 ) in Group II.

\section{Discussion}

In the present study, ketamine produced dose-dependent increases in delta-, theta-, and beta-activity. This was paralleled by dose-dependent increases in MCA blood flow velocity. These changes were not correlated with systemic haemodynamic changes or variations in PETCO $\mathrm{CO}_{2}$. Our results suggest that ketamine-induced increases in $\dot{V}$ mean are produced by neuronal activation.

In contrast to most other anaesthetics, the anaesthetic effects of ketamine are associated with activation of cerebral function resulting in synchronized theta- and desynchronized beta-activity. Kayama and Iwama reported the appearance of synchronous high-voltage slow wave activity following ketamine ( 2 to $5 \mathrm{mg} \cdot \mathrm{kg}^{-1}$ ) in unrestrained cats. ${ }^{3}$ In agreement with previous studies, ${ }^{11}$ ketamine decreased alpha-activity and increased thetaactivity with smaller increases in delta- and beta-activity. The EEG slow waves following short-lasting desynchronization has been interpreted as a correlate of ketamineinduced seizure activity in subcortical and neocortical areas. ${ }^{3,12}$ Even though no spike-and-wave complexes as an indicator for the occurrence of seizure activity or electrical correlates of myocloni were observed, the twitching of face or limb muscles seen in some volunteers may be related to these electrical phenomena.

The effect of ketamine on cerebral metabolism is controversial. ${ }^{4-8}$ It has been shown that increases in EEG activity are associated with increases in neuronal metabolism. ${ }^{13,14}$ Since cerebral metabolism was not measured in the present study it remains speculative if the appearance of high-voltage hypersynchronuous slow-wave activity are related to ketamine-induced cerebral metabolic stimulation. $^{4,7}$

Ketamine has been found to cause variable CBF changes, from an $80 \%$ increase $^{4}$ to a $50 \%$ decrease. ${ }^{5,6}$ Discontinuous CBF measurements may result in decreased sensitivity to transient changes in cerebral haemodynamics. Here, we continuously recorded intracranial blood flow velocity using noninvasive TCD-monitoring. ${ }^{9,10}$ The dose-dependent increases in MCA blood flow velocity cannot be explained by changes in HR, MAP. Even though PETCO $\mathrm{P}_{2}$ was different between groups it did not change over time in either group. In humans the cerebral vascular response to $\mathrm{CO}_{2}$ is not altered by ketamine. ${ }^{15}$ Our results are thus consistent with the view that ketamine alters cerebral haemodynamics due to its cerebral rather than to its peripheral vascular effects. ${ }^{10}$ Even though this response is not strictly linear the present study demonstrates that increases in blood flow velocity are correlated with increases in thetaactivity and EEG total power. Together, our data indicate concurrent stimulation of both neuronal activity and cerebrovascular haemodynamics.

The CBF cannot be measured directly using TCD because the diameter of the insonated vessel segment 


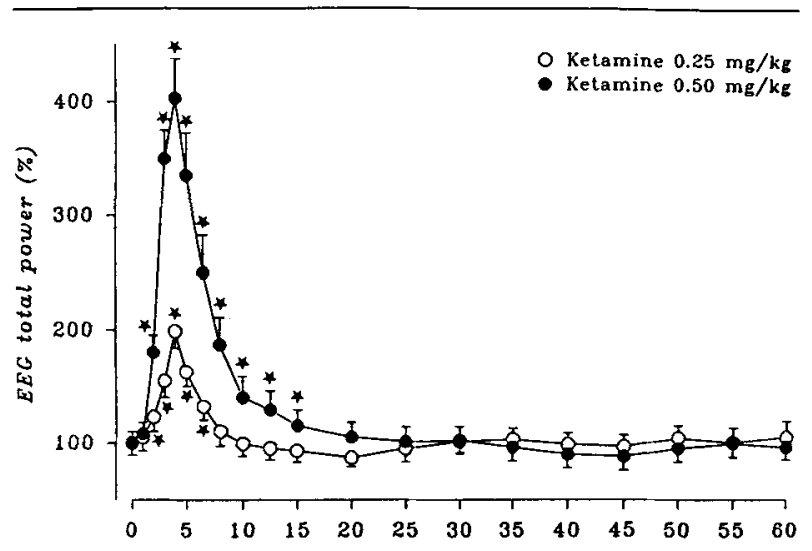

FIGURE 1 Percent changes in EEG total power (upper graph) following low-dose ketamine compared with baseline recordings (100\%). Group I: ketamine $0.25 \mathrm{mg} \cdot \mathrm{kg}^{-1}$; Group II: ketamine 0.5 $\mathrm{mg} \cdot \mathrm{kg}^{-1}\left({ }^{*} P<0.05\right.$ compared with baseline $)$.

(MCA) is unknown. However, experimental studies using anaesthetics and narcotics have shown that changes in CBF are correlated to changes in Vmean. ${ }^{16,17}$ The present experiments indicate only minor changes in the diameter of the proximal MCA under these conditions. Our data suggest that dose-dependent changes in Vmean following ketamine reflect relative $\mathrm{CBF}$ changes since the insonation angle and depth of insonantion were maintained constant over time and systemic hemodynamics were not different between groups. It is possible that MCA blood flow velocity changes following ketamine are not related to hemodynamic effects of the drug but to changes in neuronal activity.

Our study demonstrates that $0.25 \mathrm{mg} \cdot \mathrm{kg}^{-1}$ and 0.50 $\mathrm{mg} \cdot \mathrm{kg}^{-1}$ ketamine produces stimulation of brain electrical activity in parallel to dose-dependent increases in intracranial blood flow velocity. The authors conclude that simultaneous recordings of brain electrical activity and cerebral blood flow velocity may be a valuable tool for continuous monitoring of anaesthetic-induced changes of both functional and cerebral haemodynamic variables.

\section{Acknowlegement}

The authors would like to thank Dr. Irmgard Blanc for her help in editing the manuscript.

\section{References}

1 Corssen $G$, Miyasaka $M$, Domino $E F$. Changing concepts in pain control during surgery: dissociative anesthesia with CI-581, a progress report. Anesth Analg 1968; 47: 746-59.

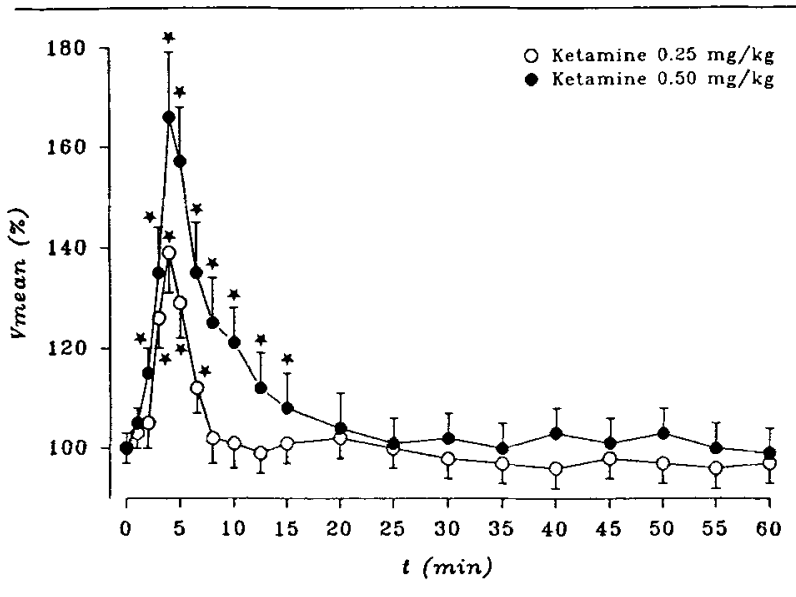

FIGURE 2 Percent changes in MCA blood flow velocity (Vmean) following low-dose ketamine, compared with baseline recordings (100\%) Group I: ketamine $0.25 \mathrm{mg} \cdot \mathrm{kg}^{-1}$; Group II: ketamine 0.5 $\mathrm{mg} \cdot \mathrm{kg}^{-1}\left({ }^{*} P<0.05\right)$

2 Mori K, Kawamata M, Mitani $H$, Yamazali $Y$, Fujita $M$. A neurophysiologic study of ketamine anesthesia in the cat. Anesthesiology 1971; 33: 373-83.

3 Kayama $Y$, Iwama $K$. The EEG, evoked potentials, and single-unit activity during ketamine anesthesia in cats. Anesthesiology 1972; 36: 316-28.

4 Dawson B, Michenfelder JB, Theye RA. Effects of ketamine on canine cerebral blood flow and metabolism: modification by prior administration of thiopental. Anesth Analg 1971; 50: 443-8.

5 Kreuscher H, Grote J. Die Wirkung des Phenyciclidin Derivates Ketamin (CI581) auf die Durchblutung und Sauerstoffaufnahme des Gehims beim Hund. Anaesthesist 1967; 16: 304-11.

6 Schwedler M, Miletich DJ, Albrecht RF. Cerebral blood flow and metabolism following ketamine administration. Can Anaesth Soc J 1982; 29: 222-5.

7 Takeshita H, Yoshiaki O, Sari A. The effects of ketamine on cerebral circulation and metabolism in man. Anesthesiology 1972; 36: 69-75.

8 Hoffman WE, Miletich DJ, Albrecht RF. Cerebrovascular response to hypotension in hypertensive rats: effect of antihypertensive therapy. Anesthesiology 1983; 58: 32632.

9 Aaslid R. Transcranial Doppler Sonography. Wien New York: Springer 1986.

10 Werner C, Kochs E, Rau M, Blanc I, Schulte am Esch $J$. Dose-dependent blood flow velocity changes in the basal cerebral arteries following low-dose ketamine. Journal of Neurosurgical Anesthesiology 1990; 2 : 86-91.

11 Kochs E, Blanc I, Werner C, Schulte am Esch J. Elec 
troencephalogram and somatosensory evoked potentials following low-dose ketamine. Anaesthesist 1988; 37 : 625-30.

12 Ferrer-Allado T, Brechner VL, Dymond A, Cozen H, Crandall $P$. Ketamine-induced electroconvulsive phenomena in the human limbic and thalamic regions. Anesthesiology 1973; 38: 333-44.

13 Ingvar DH, Sjölund B, Ardoe A. Correlation between dominant EEG frequency, cerebral oxygen uptake and blood flow. Electroencephalogr Clin Neurophysiol 1976; 41: 268-76.

14 Crosby $G$, Crane AM, Sokoioff L. Local changes in cerebral glucose utilization during ketamine anesthesia. Anesthesiology 1982; 56: 437-42.

15 Shapiro HM, Wyte SR, Harris AB. Ketamine anesthesia in patients with intracranial pathology. Br J Anaesth 1972; 44: 1200-3.

16 Werner C, Hoffman WE, Kochs E, Albrecht RF, Schulte am Esch J. The effects of propofol on cerebral blood flow in correlation to cerebral blood flow velocities in dogs. Anesthesiology 1990; 73: A556.

17 Werner C, Hoffman WE, Baughman VL, Albrecht RF, Schulte am Esch $J$. Effects of sufentanil on cerebral blood flow, cerebral blood flow velocity, and metabolism in dogs. Anesth Analg 1991; 72: 177-81. 